p-ISSN 0044-1600

e-ISSN 2392-3458

\title{
CHANGES IN DIVERSITY OF FARM INCOME IN MEMBER STATES OF THE EUROPEAN UNION
}

\author{
BARBARA CHMIELEWSKA
}

\begin{abstract}
Following enlargement of the European Union (EU) in 2004 and in the subsequent years, 13 new members, including Poland (EU-13), were covered with the Common Agricultural Policy (CAP). The introduced reforms contributed to improvement of the agrarian structure and a drop in the labour inputs in agriculture. Consequently, countries from the group of the EU-13 were characterised by higher farm income growth dynamics than countries that have been members of the EU for a much longer time (EU-15). The paper aims at assessment of whether the period following the accession was marked by real convergences (in 2010 prices) of farm incomes per labour input unit expressed in $A W U$ or whether the process was reversed - there occurred divergence between the EU Member States, especially between the group of the EU-13 and the EU-15. To this end, comparative analysis method was used relying on measure of diversity of distribution used in statistics. The study was mainly based on the Economic Accounts for Agriculture (EAA, Eurostat). The study covers the years between 2004 and 2016.
\end{abstract}

Keywords: farm income, accession, diversity, Member States of the European Union.

JEL codes: D00, Q12, Q14.

Dr hab. Barbara Chmielewska, prof. IERiGŻ-PIB, Instytut Ekonomiki Rolnictwa i Gospodarki ŻywnościowejPaństwowy Instytut Badawczy, Zakład Ogólnej Ekonomiki; ul. Świętokrzyska 20, 00-002 Warszawa (barbara.chmielewska@ierigz.waw.pl) 


\section{Introduction}

Convergence means the process of levelling (catching up with) various areas of activities within e.g. countries, regions or specific groups. The convergence classification method depends on the adopted criterion. Matkowski, Próchniak and Rapacki (2013b, p. 1) claim that "the concept of convergence (...) has many other aspects, such as convergence of production and organizational structures, levelling of technology, assimilation of institutions and even cultural patterns, as well as synchronization of business fluctuations". Convergence may, therefore, apply to regulations, as well as technology, lifestyle, income, financial markets or it can be nominal (Maastricht criteria) (Woźniak, 1993; Jabłoński, 2012).

This study considers one aspect of convergence, namely the tendency towards levelling income from agriculture among countries with different levels of economic and social development in the European Union. Convergence is, thus, understood as the process of catching up with the level of real agricultural income/ AWU (in 2010 prices) achieved by countries that have been Member States of the EU for a longer period.

According to Matkowski, Próchniak and Rapacki (2013a), less developed countries are developing faster than those more developed and, consequently, they are gradually catching up with them in terms of the development level. Empirical analyses covering large and diversified groups of countries seem not to confirm the convergence phenomenon, proving that worldwide income diversification is growing. However, smaller and more homogeneous groups, especially groups characterized by a similar level of development, which are bound by integration ties, such as the European Union, usually note a more or less marked convergence trend. Stiglitz (2015) emphasizes that the convergence process is affected by a number of interrelated factors. Convergence results may, therefore, vary depending on the analysed period and group, as well as the type and source of the data and the analysis method.

\section{Purpose and method}

The purpose of the paper is to assess the diversity and changes in the level of agricultural income among the EU Member States, especially their two groups: the group of 15 countries (EU-15) that were EU members before its major enlargement (in 2004) and the group of 13 new countries (EU-13) that joined the EU between 2004 and 2013. The study covered the category of real (in 2010 prices) agricultural income per AWU ${ }^{1}$. For stylistic reasons, terms like income, real agricultural income, agricultural income/AWU are used in the paper interchangeably, but they invariably mean the same income category, namely real (in 2010 prices) agricul-

\footnotetext{
${ }^{1}$ AWU (Annual Work Unit) - a conventional unit of labour input in agriculture, meaning a full-time equivalent. It is calculated by dividing the number of hours of work per year by the annual number of hours corresponding to a full-time equivalent. In Poland, a full-time equivalent is 2120 hours of work in the year, i.e. 265 working days multiplied by 8 hours of work a day. When calculating the labour input in AWU (in accordance with the Eurostat's methodology), it is assumed that there can be no more than 1 AWU per person, even if in reality one person works longer (Pojęcia stosowane w statystyce publicznej, 27/03/2018, https).
} 
tural income per AWU. The Economic Accounts for Agriculture (EAA) ${ }^{2}$ based on Eurostat's statistical data are the key database used in the study. The study covers the 2004-2016 period. It was examined whether the post-accession period was characterized by the process of convergence of real (in 2010 prices) agricultural income per AWU, or maybe the opposite process, i.e. divergence between the EU Member States, was recorded. To this end, the comparative analysis method was applied, using the measures of spread applied in statistics, such as: mean value, median, standard deviation and coefficient of variation.

Income is a key economic category and means "all proceeds generated by a business unit within a fixed period less the cost of their generation" (Encyklopedia $P W N, 27 / 09 / 2017)$. It is, therefore, the difference between the obtained revenue and the incurred cost. In terms of cash, it represents goods and services that can be bought for it by entities generating income. In the macroeconomic approach, it is an economic margin that can be used to meet individual and collective needs, current (consumption) and development goals (for investments) (Owsiak, 2015). In practice, various entities define their income in various ways. In the case of certain groups of entities, income is defined by law (e.g. income calculated for specific purposes such as determination of benefit amounts or the tax rate) (Pawłowska-Tyszko and Soliwoda, 2014).

Calculation of income is associated with major methodological difficulties and those relating to figures, mainly due to the need to estimate a large number of items in the income statement. This results both from respondents' reluctance to disclose real income as well as methodical problems, both on the macro- and microscale.

Agricultural income is income generated as a result of agricultural production, and it is the purpose of farming. In the case of agricultural income, it is necessary to distinguish between (1) income generated as a result of agricultural production (gross value added) and (2) income of agricultural households, as the latter may have, besides income from agricultural production, other income sources (agricultural and non-agricultural) (Zegar, 2008a; Zegar, 2008b)³.

\footnotetext{
${ }^{2}$ In the EAA system, agricultural income is determined on the basis of macroeconomic accounts for the entire agricultural sector. Besides the volume and value of farms' output in a given year, the value of secondary non-agricultural activities, whose costs cannot be excluded from the production process, is also taken into account. The entrepreneur's net income is a synthetic measure of the level of remuneration for unpaid labour resources, compensation for invested capital and ground rent. Agricultural income calculated based on the EAA is recognized also per annual work unit (AWU) (Buks, 2015; Zawalińska, Majewski and Wąs, 2015).

${ }^{3}$ In the Encyklopedia Agrobiznesu agricultural income is defined as part of the farm's output which remains after deducting all contributions and liabilities payable to the state budget, other economic entities and persons (e.g. remuneration for hired labour). It is the income of an agricultural producer for his own labour and that of his family (Encyklopedia Agrobiznesu, 1998).
} 
In order to determine the income situation in agriculture, three key databases are used, i.e.:

1. Economic Accounts for Agriculture (EAA)

2. Polish FADN - accounting data from farms covered by the agricultural accounting system ${ }^{5}$;

3. Household budgets - database kept by the Central Statistical Office (Główny Urząd Statystyczny, GUS), EU-SILC ${ }^{6}$.

Each of the three mentioned databases is characterized by a slightly different methodology of obtaining data, hence the income results may differ, but the change trends are similar.

The Economic Accounts for Agriculture method was developed and unified by Eurostat and is used to calculate the volume and value of agricultural production in the European Union countries. The EAA use the same calculation system in all Member States, which makes it possible to compare output and economic results and to monitor agricultural income in the EU. In Poland, the EAA have been prepared since 1998 by the Institute of Agricultural and Food Economics - National Research Institute in close cooperation with the Central Statistical Office (RER, http://www.ierigż.waw.pl/prace badawcze).

\section{Differentiation in the level and dynamics of agricultural income in the EU Member States}

Real agricultural income/AWU in the EU-15 countries is much higher than in the EU-13. At the beginning of the accession period (2005), the Netherlands, Denmark and Belgium, with income above EUR 30 thousand and more, led in the ranking according to the level of real agricultural income/AWU/year (from the highest to the lowest one). These countries were followed by Luxembourg, Spain, France, the United Kingdom, Finland and Germany (EUR 20-30 thousand). Lower income was recorded in Ireland, Italy, Austria, Sweden and Greece (EUR 10-20 thousand). This group also included three EU-13 countries: Malta, Cyprus and the Czech Republic. Income below EUR 10 thousand was recorded in the other ten EU-13 countries and in one EU-15 country (Portugal). However, it should be emphasized that in both groups of countries, old and new EU members, there was a significant differentiation in the level of the examined income category (Table 1, Fig. 1).

\footnotetext{
${ }^{4}$ See Buks (2015); Gołaś (2015).

${ }^{5}$ See Floriańczyk, Osuch and Płonka (2017).

${ }^{6}$ See Gus (2011); Zegar (1999); Chmielewska (2013).
} 
Table 1

Differentiation in the level of real agricultural income

Countries ranked according to real Countries ranked according to real agricultural income/AWU in 2016
agricultural income/AWU in 2005 agricultural income/AWU in $2005-$ - from the highest to the lowest income

\begin{tabular}{|c|c|c|c|c|c|c|}
\hline Countries & $\begin{array}{c}\text { Agricultural } \\
\text { income/AWU } \\
\text { in EUR per year }\end{array}$ & Countries & $\begin{array}{c}\text { Agricultural } \\
\text { income/AWU } \\
\text { in EUR per year }\end{array}$ & $\begin{array}{c}\text { Changes } \\
\text { in } \\
2005-2016\end{array}$ & \multicolumn{2}{|c|}{$\begin{array}{l}\text { Relative to the EU } \\
\text { average, } \%\end{array}$} \\
\hline 2005 & 2005 & 2016 & 2016 & $2005=100$ & 2005 & 2016 \\
\hline EU-28 & 11087 & EU-28 & 14762 & 133.1 & 100 & 100 \\
\hline \multicolumn{7}{|c|}{ EU-15 } \\
\hline EU-15 & 20476 & EU-15 & 22870 & 111.7 & $\mathrm{x}$ & $\mathrm{x}$ \\
\hline Netherlands & 39979 & Netherlands & 49734 & 124.4 & 360.6 & 336.9 \\
\hline Denmark & 33664 & Belgium & 31034 & 104.8 & 267.1 & 210.2 \\
\hline Belgium & 29613 & Spain & 30441 & 121.8 & 225.4 & 206.2 \\
\hline Luxembourg & 27857 & United Kingdom & 29653 & 123.8 & 216.0 & 200.9 \\
\hline Spain & 24994 & France & 26967 & 111.1 & 219.0 & 182.7 \\
\hline France & 24282 & Denmark & 22978 & 68.3 & 303.6 & 155.7 \\
\hline United Kingdom & 23951 & Sweden & 25520 & 128.5 & 179.2 & 172.9 \\
\hline Finland & 21374 & Germany & 20117 & 98.0 & 185.1 & 136.3 \\
\hline Germany & 20524 & Luxembourg & 19135 & 68.7 & 251.3 & 129.6 \\
\hline Sweden & 19867 & Italy & 18047 & 105.0 & 155.0 & 122.3 \\
\hline Ireland & 19365 & Ireland & 17047 & 88.0 & 174.7 & 115.5 \\
\hline Italy & 17184 & Finland & 16424 & 76.8 & 192.8 & 111.3 \\
\hline Austria & 16147 & Austria & 16343 & 101.2 & 145.6 & 110.7 \\
\hline Greece & 13501 & Greece & 14103 & 104.5 & 121.8 & 95.5 \\
\hline Portugal & 7779 & Portugal & 10377 & 133.4 & 70.2 & 70.3 \\
\hline \multicolumn{7}{|c|}{ EU-13 } \\
\hline Malta & 17247 & Czech Republic & 19051 & 181.9 & 94.5 & 129.1 \\
\hline Cyprus & 13978 & Slovakia & 14665 & 264.3 & 50.0 & 99.3 \\
\hline Czech Republic & 10475 & Cyprus & 14486 & 103.6 & 126.1 & 98.1 \\
\hline Estonia & 8333 & Malta & 12239 & 71.0 & 155.6 & 82.9 \\
\hline Slovakia & 5549 & Hungary & 9101 & 208.7 & 39.3 & 61.6 \\
\hline Slovenia & 5231 & Estonia & 8833 & 106.0 & 75.2 & 59.8 \\
\hline Hungary & 4360 & Bulgaria & 6500 & 201.6 & 29.1 & 44.0 \\
\hline Croatia & 4183 & Lithuania & 6330 & 177.3 & 32.2 & 42.9 \\
\hline Lithuania & 3571 & Latvia & 6031 & 191.4 & 28.4 & 40.9 \\
\hline Bulgaria & 3225 & Slovenia & 5358 & 102.4 & 47.2 & 36.3 \\
\hline Latvia & 3152 & Croatia & 4971 & 118.8 & 37.7 & 33.7 \\
\hline Poland & 2831 & Poland & 4962 & 175.3 & 25.5 & 33.6 \\
\hline Romania & 2620 & Romania & 4960 & 189.3 & 23.6 & 33.6 \\
\hline
\end{tabular}

Source: own study based on Eurostat's data. Data relating to real agricultural income/AWU in 2010 prices applicable in 2017. 


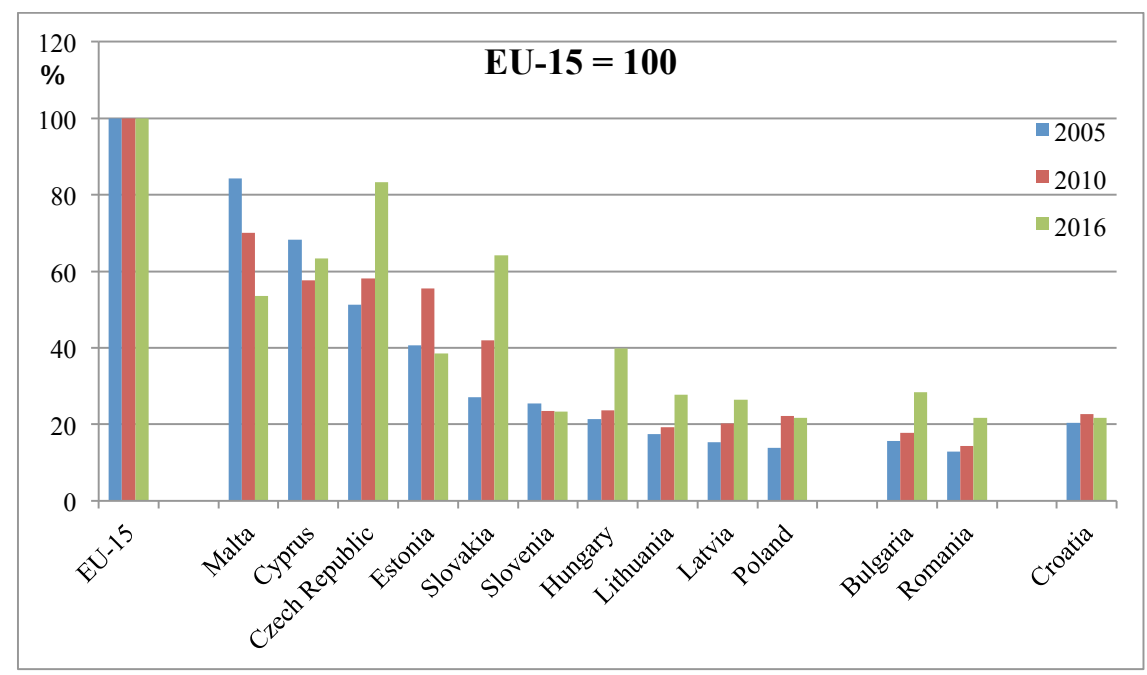

${ }^{\text {a }}$ Real agricultural income/AWU (in 2010 prices).

Fig. 1. Agricultural incomea in the EU-13 countries relative to the EU-15 average (\%).

Source: own study based on Eurostat's data from EAA.

The post-enlargement period (2005-2016) witnessed an improvement in the income situation in the EU agriculture. Average real income from agriculture/AWU increased in the EU-28 by $33 \%$, but in particular countries the dynamics of change varied. An increase was recorded in all EU-13 countries (except for Malta) and in most EU-15 countries (except for Denmark, Germany, Luxembourg, Ireland and Finland). The income growth rate was higher in the new Member States. In the EU-13, an over two-fold increase was recorded in Slovakia, Hungary and Bulgaria. A high, almost two-fold increase was recorded in Latvia, Lithuania, Romania, the Czech Republic and Poland. In other countries, the increase ranged from few to a dozen or so per cent, whereas in the EU-15, the increase ranged from $28 \%$ in Sweden to $1.2 \%$ in Austria. In the period concerned, there were no radical changes in the ranking of countries according to the level of agricultural income, in particular as regards the first and last positions, but the disproportions in income between the countries with the highest and the lowest income became much less profound. The difference between the highest and the lowest values in this category decreased in 2005-2016 as follows: in the EU-28 - from 15.2 to 10 times, in the EU-15 from 5.1 to 4.8 times and in the EU-13 - from 6.6 to 3.8 times. 


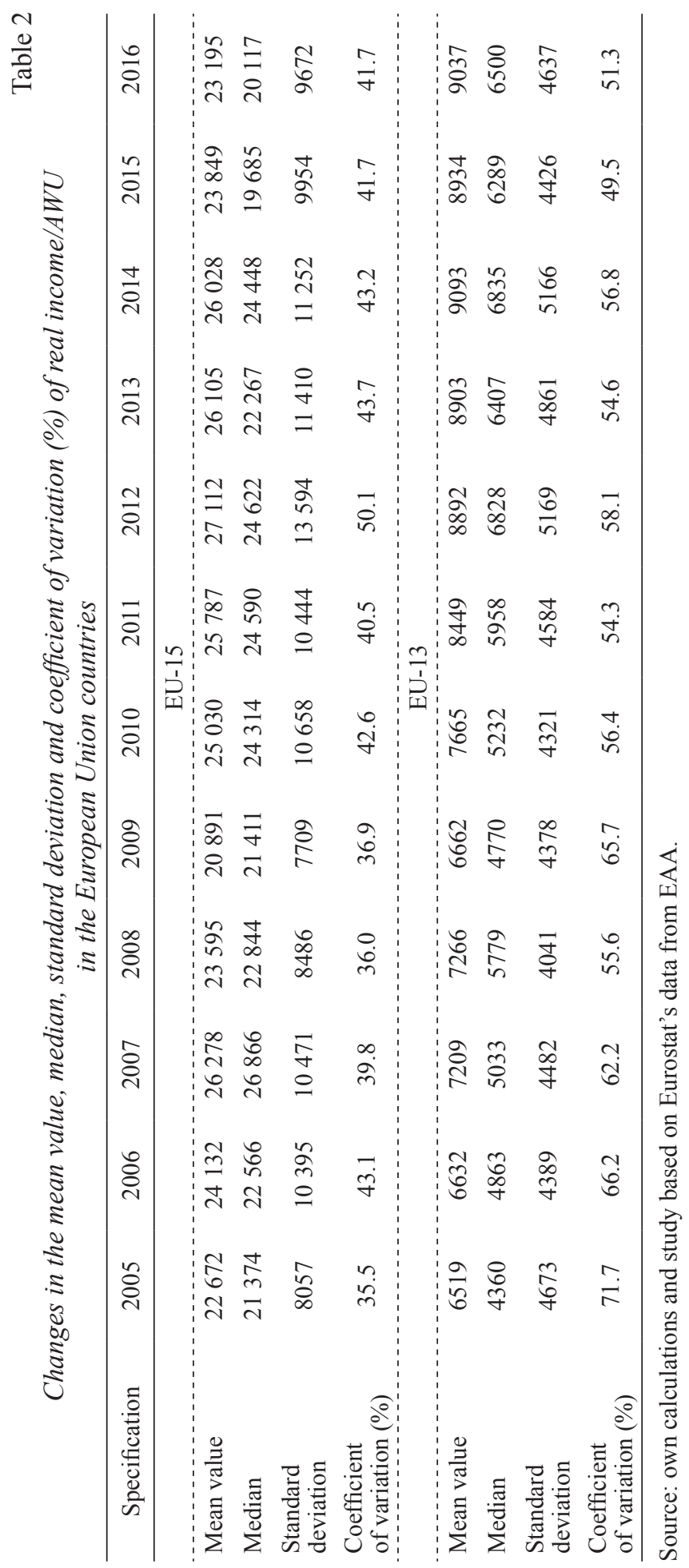


After Poland's integration with the EU, the level of real agricultural income/ AWU got closer (although this was not a constant trend over the entire period) to the average value in the EU-15, in all EU-13 countries, except for Malta, Cyprus, Estonia and Slovenia. The advantage of the EU-15 income over that of the EU-13 decreased. Convergence was a consequence of the lower growth rate in countries that had been EU members for a longer time than in those that joined the Union in 2004 and in subsequent years. However, in the case of Cyprus, Malta, Estonia and Slovenia, a divergence effect was observed - in these countries the level of income deviated from the average (the growth rate was lower than the EU-15 average).

Based on the presented changes it can be stated that the post-accession period was characterized by a convergence process (except for a few cases of divergence) of real agricultural income/AWU in the EU. The differences between the states as regards this category of income became less apparent, especially those between the new and the old Member States. This direction of changes is confirmed through systematic research on the convergence between Central and Eastern European (CEE) countries and Western Europe, conducted since 2003 by Matkowski et al. (2013a). Their research showed a moderate trend to level income in the entire European Union and a much more pronounced trend to converge the economies of the new and old members of the Union, i.e. to level income between the countries of Central and Eastern Europe and Western European countries.

The following statistics were used to present changes in the levels of real income/AWU in the EU countries and relations between them: mean value, median, standard deviation and coefficient of variation (V) (Table 2).

The standard deviation of real agricultural income/AWU calculated for the entire EU-28 was characterized by fluctuations in 2005-2012. Its interpretation may indicate alternate convergence and divergence processes. Since 2012, the value of standard deviation dropped steadily, which indicates a decrease in the spread of income around the mean, and thus its smaller variation. The lower value of standard deviation in 2016 compared to 2005 confirms that despite periodic fluctuations, there was a tendency in the post-accession period to level agricultural income among the EU countries. The value of standard deviation on average for the entire EU was a resultant of an increase in the average value of the measure in the EU-15 and a decrease in the EU-13. The higher value of standard deviation in 2016 compared to 2005, in the EU-15, indicates an increase in income differentiation in this group in the postaccession period. But then, the drop in the value of standard deviation in the EU-13 (less affluent countries) indicates a tendency to level income in this group.

Another measure of the dispersion of agricultural income in the EU is the coefficient of variation $(\mathrm{V})^{7}$. In 2005-2016, moderate variation was demonstrated on average in the EU-28, and the $\mathrm{V}$ value decreased from $69.3 \%$ to $63.0 \%$. The upward trend (although fluctuations were also recorded in the analysed period) in the value of this measure indicates a decline in income dispersion in the EU agriculture. Although the EU-15 was characterized by low variation, the value of the measure

${ }^{7}$ Low variation: $\mathrm{V}<50 \%$; moderate variation: $50 \%<\mathrm{V}<100 \%$; high variation: $\mathrm{V}>100 \%$. 
in the analysed period showed an almost constant upward trend (from 35.5\% to $41.7 \%$ ), and approached the level of the lower limit of moderate variation. There was an increase in income dispersion in this group of countries; at the same time, opposite trends were recorded in the EU-13. At the beginning of the accession process the value of the coefficient of variation indicated moderate variability (71.7 in 2005), but in subsequent years, the value of this indicator was decreasing to reach $51.3 \%$ in 2016 , so it approached the level of the upper limit of small variation. The decrease in the value of the coefficient of variation indicates a decrease in the income dispersion in the countries that joined the EU in the analysed period.

Changes in the level of agricultural income per AWU in the EU, especially its relations between the old and the new Member States, are determined by numerous factors. Although their impact is not the subject of this study, it would be worthwhile to point out at least two key aspects, namely financial support for agriculture under the CAP (see Zieliński (ed.), Sobierajska, Mirkowska i Osuch, 2011) and changes in labour input in agriculture (see Sredzińska, 2017). After accession to the European Union, agriculture in thirteen new Member States received major financial support earmarked, e.g. for direct payments, which translated directly into an improvement in the farmers' income situation. The new EU countries are characterized by a higher growth rate of funds earmarked for direct payments. According to Poczta (ed.) (2013), the value of funds earmarked for direct payments increased in 2007-2013 in the EU-12 (without Croatia) two and a half times. In the EU-27, a 14\% increase was recorded, with a 5\% increase in the EU-15. The EU-13 countries were also characterized by a higher rate of decline in labour input in agriculture. In 2016, compared to 2005, agricultural labour input in AWU was lower in the EU- 15 countries by $35 \%$ in Portugal to $2.9 \%$ in the United Kingdom, while in the EU-13 countries, the decline was in the range from 59\% in Bulgaria, 54\% in Romania and 52\% in Slovakia to 15\% in Lithuania and in Poland and 11\% in Slovenia. Both the EU funds supporting the agricultural sector in the EU-13 countries and better use of agricultural labour in these countries helped them to catch up with the higher level of agricultural income recorded in the EU-15 countries.

\section{Real agricultural income per AWU in Poland compared to other EU Member States}

Joining the European Union in 2004, Poland was a country in which real agricultural income per AWU was at a low level - below the EU average. In fixed prices from 2010, this income amounted to: EUR 2831 in 2005, EUR 5698 in 2013 (the highest level) and EUR 4962 in 2016. The greatest differences in this regard were recorded with respect to the Netherlands, Denmark and Belgium, where income in the first year after accession was as much as 10-14 times higher than in Poland. In the other old EU countries, this difference was slightly lower, but also high (6-9-fold). The smallest difference was observed in relation to the poorest EU-15 Member States, such as Greece and Portugal, but also in these countries agricultural income was almost three and five times higher than in Poland ${ }^{8}$.

\footnotetext{
${ }^{8}$ The author's own calculations based on Eurostat's data from EAA.
} 
Table 3

Relations between the levels of real agricultural income/AWU (in 2010 prices) in the EU Member States (Poland = 100)

\begin{tabular}{|c|c|c|c|c|c|c|c|c|c|c|c|c|}
\hline Countries & 2005 & 2006 & 2007 & 2008 & 2009 & 2010 & 2011 & 2012 & 2013 & 2014 & 2015 & 2016 \\
\hline \multicolumn{13}{|c|}{ Poland $=100(\%)$} \\
\hline EU-28 & 392 & 367 & 334 & 367 & 294 & 273 & 263 & 277 & 270 & 296 & 300 & 298 \\
\hline \multicolumn{13}{|c|}{ EU-15 } \\
\hline Belgium & 1046 & 1166 & 1035 & 942 & 791 & 790 & 619 & 801 & 601 & 637 & 715 & 625 \\
\hline France & 858 & 861 & 798 & 776 & 566 & 615 & 565 & 609 & 479 & 595 & 646 & 544 \\
\hline Netherlands & 1412 & 1544 & 1239 & 1256 & 940 & 926 & 707 & 819 & 853 & 913 & 934 & 1002 \\
\hline Luxembourg & 984 & 867 & 850 & 818 & 445 & 398 & 348 & 396 & 318 & 471 & 378 & 386 \\
\hline Germany & 725 & 714 & 729 & 872 & 562 & 488 & 560 & 501 & 632 & 499 & 385 & 405 \\
\hline Italy & 607 & 531 & 430 & 496 & 430 & 299 & 311 & 357 & 391 & 396 & 399 & 364 \\
\hline Denmark & 1189 & 1215 & 1007 & 650 & 588 & 797 & 787 & 1152 & 741 & 928 & 622 & 463 \\
\hline Ireland & 684 & 510 & 460 & 468 & 321 & 281 & 309 & 296 & 283 & 329 & 331 & 344 \\
\hline $\begin{array}{l}\text { United } \\
\text { Kingdom }\end{array}$ & 846 & 765 & 656 & 941 & 856 & 620 & 636 & 646 & 644 & 705 & 627 & 598 \\
\hline Greece & 477 & 413 & 365 & 411 & 416 & 308 & 236 & 253 & 216 & 256 & 294 & 284 \\
\hline Spain & 883 & 765 & 706 & 677 & 601 & 490 & 436 & 473 & 481 & 553 & 591 & 614 \\
\hline Portugal & 275 & 247 & 193 & 242 & 182 & 166 & 122 & 144 & 155 & 175 & 186 & 209 \\
\hline Austria & 570 & 581 & 539 & 591 & 399 & 368 & 372 & 374 & 302 & 316 & 304 & 329 \\
\hline Finland & 755 & 675 & 640 & 628 & 629 & 532 & 404 & 428 & 387 & 387 & 318 & 331 \\
\hline Sweden & 702 & 722 & 719 & 716 & 493 & 491 & 439 & 467 & 389 & 478 & 520 & 514 \\
\hline \multicolumn{13}{|c|}{ EU-13 } \\
\hline Cyprus & 494 & 403 & 331 & 356 & 339 & 259 & 170 & 252 & 231 & 238 & 272 & 292 \\
\hline $\begin{array}{l}\text { Czech } \\
\text { Republic }\end{array}$ & 370 & 352 & 326 & 399 & 288 & 261 & 309 & 329 & 307 & 394 & 353 & 384 \\
\hline Estonia & 294 & 265 & 301 & 262 & 196 & 249 & 273 & 340 & 291 & 306 & 258 & 178 \\
\hline Lithuania & 126 & 101 & 125 & 130 & 99 & 86 & 97 & 130 & 108 & 110 & 126 & 128 \\
\hline Latvia & 111 & 130 & 112 & 107 & 92 & 91 & 77 & 99 & 83 & 98 & 126 & 122 \\
\hline Malta & 609 & 540 & 432 & 453 & 448 & 315 & 241 & 244 & 222 & 243 & 266 & 247 \\
\hline Poland & 100 & 100 & 100 & 100 & 100 & 100 & 100 & 100 & 100 & 100 & 100 & 100 \\
\hline Slovakia & 196 & 217 & 188 & 236 & 161 & 189 & 197 & 237 & 214 & 262 & 271 & 296 \\
\hline Slovenia & 185 & 162 & 149 & 149 & 125 & 105 & 106 & 91 & 86 & 109 & 122 & 108 \\
\hline Hungary & 154 & 150 & 132 & 196 & 118 & 106 & 139 & 136 & 139 & 165 & 163 & 183 \\
\hline Bulgaria & 114 & 100 & 82 & 150 & 93 & 80 & 80 & 100 & 112 & 134 & 128 & 131 \\
\hline Romania & 93 & 83 & 53 & 89 & 67 & 65 & 73 & 57 & 63 & 76 & 78 & 100 \\
\hline Croatia & 148 & 156 & 132 & 171 & 145 & 102 & 86 & 78 & 75 & 77 & 93 & 100 \\
\hline
\end{tabular}

Source: own calculations based on Eurostat's data from EAA. 
Real income from agriculture in Poland was also lower compared to countries that joined the EU together with Poland. Income disproportions to Poland's disadvantage were lower than when compared to the EU-15 countries, but also high and ranged from a 6-fold advantage in Malta, almost a 5-fold one in Cyprus and a 3.7-fold one in the Czech Republic to $11 \%$ in Latvia. Only in Romania it was lower than in Poland.

A significant improvement in the income situation in Polish agriculture occurred after integration with the EU, as indicated by a decrease in the agricultural income advantage in all EU-15 countries relative to Poland. In a few of them, even an over or almost 2-fold decrease was recorded (e.g. in Denmark - from 12 to 4.6 times, Finland - from 7.5 to 3.3 times, and Germany - from 7.2 to 4 times). However, compared to the EU-13 countries, this advantage decreased only in Cyprus and Malta as well as Estonia, Slovenia and Croatia. In the others, the differences increased to the disadvantage of Poland. The greatest advantage in agricultural income/AWU was recorded in the Czech Republic (by 3.8 times) and in Slovakia (by almost 3 times), as shown in Table 3.

The reduction in disproportions in real agricultural income/AWU in Poland relative to the EU-15 after Poland's accession to the European Union resulted from e.g. changes that occurred in Poland in 2005-2016:

- A higher rate of growth of real agricultural income/AWU (an increase by $75 \%$ ) compared to the average growth in the EU-28 (by 33\%) and the EU-15 (by $12 \%)^{9}$; and greater total subsidies to agriculture (by 125\%) and the proportion of subsidies in the income of an agricultural entrepreneur - from $46 \%$ to $50 \%{ }^{10}$.

- A lower employment level in agriculture; labour input in AWU decreased by 15\% (from 2292 thousand to 1193 thousand). There was, however, an improvement in the use of labour resources - the proportion of full-time employees (AWU) in the total number of natural persons employed in agriculture increased from $45 \%$ to $54 \%{ }^{11}$.

- A better structure of farms with respect to economic size classes, mainly an increase in the percentage of large farms and a decrease in medium-sized ones ${ }^{12}$.

- Greater specialization in farm production, as shown by changes in the structure of farms by farming types. There was an increase in the proportion of farms specializing mainly in dairy farming (from 6 to $13 \%$ ) and in field crops (from $21 \%$ to $24 \%$ ), and a decrease in the proportion of those specializing in mixed farming (from 53\% to 44\%) (Goraj et al., 2006; Floriańczyk et al., 2017).

\footnotetext{
${ }^{9}$ EAA Eurostat.

${ }^{10}$ EAA Eurostat.

${ }^{11}$ Refers to the total labour force, i.e. family and non-family labour, as well as that of hired workers working permanently and seasonally in 2005-2013. (European Union, Statistical Factsheet, European Commission, Eurostat, 2017).

${ }^{12}$ In 2005, the European Size Unit (ESU, one ESU equals EUR 1200) was the parameter used to determine the economic size of a farm. In 2016, the economic size of a farm was expressed in SO in euro (the sum of the values of standard output). In 2005, mid-sized farms (8-40 ESU) accounted for 32.9\%, and large ones (40-100 ESU) for 1.3\%. In 2016, mid-sized farms (EUR 25-200 thousand) accounted for 17.9\%, and large ones (EUR 100-500 thousand) for 2.2\%. More information on parameters used to determine the economic size of a farm in 2005 and in 2016 can be found in Goraj et al. (2006); Floriańczyk et al. (2017).
} 
- A smaller number of farms, mainly small ones, and a better area structure of private farms. The total number of farms with an area of more than 1 ha decreased by $22 \%$. There was a decline in the number of farms with an area of up to 30 ha of UAA (the highest, by $39 \%$, in the case of those with an area of 1-2 ha, and the lowest, by 4\%, in the case of those with an area of 20-30 ha). Then, there was an increase in the number of farms with an area of over 30 ha (from $18 \%$ in the case of those with an area of 30-50 ha to $53 \%$ in the case of those with an area of 500-1000 ha). The highest increase in the number of farms was recorded in the area group of 1,000 ha and more (by more than three times). In the structure of farms, it is, however, only a few hundredths of a percent. As regards the area structure of private farms, it was characterized by a decrease in the proportion (from $25 \%$ to $19 \%$ ) of the smallest farms (1-2 ha) and an increase in the proportion of large ones (30-1000 ha) - from 3\% to $5 \%{ }^{13}$.

\section{Conclusions}

The period after the accession of Poland and other Member States to the European Union in 2004 and subsequent years was characterized by the process of convergence (except for few cases of divergence) of real income from agriculture per fulltime equivalent, expressed in AWU. Despite periodic fluctuations, the levels of this category of income in the EU Member States were converging, especially when it comes to the relation between the EU-15 and EU-13 groups. There was a decrease in the agricultural income advantage in countries that had been EU Member States for a long time relative to the new EU countries. This was directly attributable to the rate of growth of agricultural income in the EU-13 which was higher than in the EU-15. Countries with lower agricultural income were catching up with those with a higher level of agricultural income. In spite of an evident tendency toward convergence between the EU-13 and the EU-15 as regards real agricultural income/ AWU observed after the accession, this type of income is still much lower in most EU-13 countries compared to the EU-15 Member States.

\footnotetext{
13 The author's own calculations based on: Charakterystyka gospodarstw rolnych w 2005 r. (2006); Charakterystyka gospodarstw rolnych w 2016 r. (2017). Large farms are farms with UAA of more than 30 ha, as cited in: Kania (2013); Musiał (2013); Poczta, Czubak, Kiryluk-Dryjska, Sadowski and Siemiński (2012).
} 


\section{References}

Buks, J. (2015). Wykorzystanie Rachunków Ekonomicznych dla Rolnictwa (RER) do mierzenia dochodu w sektorze rolnym. W: Wyzwania współczesnej gospodarki-aspekty teoretyczne i praktyczne (pp. 73-81). Warszawa: Wydawnictwo SGGW.

Chmielewska, B. (2013). Ekonomiczno-społeczna sytuacja gospodarstw domowych rolników po akcesji Polski do Unii Europejskiej. Studia i Monografie, no. 158. Warszawa: IERiGŻ-PIB.

Encyklopedia Agrobiznesu (1998). Hasło oprac. przez J.S. Zegara. Warszawa: Fundacja Innowacja.

European Union, Statistical Factsheet, European Commission, Eurostat, June 2017 (data update March 2017).

Floriańczyk, Z., Osuch, D., Płonka, R. (2017). Wyniki Standardowe w 2016 uzyskane przez gospodarstwa rolne uczestniczace w Polskim FADN. Część I. Warszawa: IERiGŻ-PIB.

Gołaś, Z. (2015). Systemy wskaźników dochodowości pracy w rolnictwie-propozycja metodyczna. Materiał źródłowy i metody badawcze. Zeszyty Naukowe Szkoły Głównej Gospodarstwa Wiejskiego, Ekonomika i Organizacja Gospodarki Żywnościowej, no. 109, pp. 17-26.

Goraj, L., Osuch, D., Suska, M., Bańkowska, K., Grabowska, K., Madej, P., Malanowska, B., Smolik, A., Żurakowska, J. (2006). Wyniki Standardowe uzyskane przez gospodarstwa rolne uczestniczace w Polskim FADN w 2005 roku. Warszawa: IERiGŻ-PIB.

GUS (2006). Charakterystyka gospodarstw rolnych w 2005 roku. Warszawa.

GUS (2011). Metodologia Badania Budżetów Gospodarstw Domowych. Departament Warunków Życia. Warszawa: Zakład Wydawnictw Statystycznych.

GUS (2017). Charakterystyka gospodarstw rolnych w 2016 roku. Warszawa.

Jabłoński, Ł. (2012). Kapitał ludzki a konwergencja gospodarcza. Warszawa: Wydawnictwo C.H. Beck.

Kania, J. (2013). Drobne gospodarstwa rolne - stan aktualny i perspektywy na przyszłość. Prezentacja, na konferencji pt. Przyszłość drobnych gospodarstw rolnych. Szczyrk, Uniwersytet Rolniczy w Krakowie.

Musiał, W. (2013). Problemy ekonomiczne gospodarstw małych i ich oczekiwania wobec reformy WPR 2014-2020. In: Problemy społeczne i ekonomiczne drobnych gospodarstw rolnych w Europie. Kraków. Publikacja opracowana w związku z realizacją projektu „Trzecia, międzynarodowa konferencja: Problemy społeczne i ekonomiczne drobnych gospodarstw rolnych w Europie" w ramach Planu działania Sekretariatu Centralnego Krajowej Sieci Obszarów Wiejskich na lata 2012-2013.

Owsiak, S. (2015). Finanse. Warszawa: Polskie Wydawnictwo Ekonomiczne.

Pawłowska-Tyszko, J., Soliwoda, M. (2014). Dochody gospodarstw rolniczych a konkurencyjność systemu podatkowego i ubezpieczeniowego. Program Wieloletni 2011-2014, no. 121. Warszawa: IERiGŻ-PIB.

Poczta, W., Czubak, W., Kiryluk-Dryjska, E., Sadowski, A., Siemiński, P. (2012). Koncepcja ukierunkowania wsparcia gospodarstw rolnych $w$ perspektywie 2014-2020. Poznań. Ekspertyza wykonana dla MRiRW.

Poczta, W. (red.). (2013). Gospodarstwa rolne w Polsce na tle gospodarstw Unii Europejskiejwplyw WPR. Powszechny Spis Rolny 2010. Warszawa: GUS.

Rachunki Ekonomiczne Rolnictwa (RER). Eurostat.

Stiglitz, J.E. (2015). Cena nierówności. W jaki sposób dzisiejsze podziały społeczne zagrażają naszej przyszłości?. Warszawa: Wydawnictwo Krytyki Politycznej. 
Średzińska, J. (2017). Czynniki kształtujące dochody gospodarstw rolnych Unii Europejskiej według klas wielkości ekonomicznej. Prace Naukowe Uniwersytetu Ekonomicznego we Wrocławiu, no. 477, pp. 305-314.

Woźniak, M.G. (1993). Kierowanie. Rynek. Transformacja. Bariery stabilizacji. Kraków: Instytut Badań Rynkowych.

Zawalińska, K., Majewski, E., Wąs, A. (2015). Długookresowe zmiany w dochodach z polskiego rolnictwa na tle krajów UE. Roczniki Naukowe SERiA, t. XVII, z. 6, pp. 347-348.

Zegar, J.S. (1999). Metody pomiaru dochodów chłopskich. Warszawa: IERiGŻ.

Zegar, J.S. (2008a). Dochody w rolnictwie w okresie transformacji i integracji europejskiej. Warszawa: IERiGŻ-PIB.

Zegar, J.S. (2008b). Dochody w rolnictwie (metodologia, stan i tendencje). Referat na konferencji IERiGŻ-PIB. Warszawa, SGGW, 4 Juny 2008.

Zieliński, M. (red.), Sobierajska, J., Mirkowska, Z., Osuch, D. (2011). Wyznaczenie wartości dodanej brutto dla gospodarstw korzystajacych z pomocy w ramach PROW 2007-2013. Ekspertyza na zamówienie MRiRW. IERiGZ̈, 2011.

Internet references:

Encyklopedia PWN. Retrieved from: https://sjp.pwn.pl/slowniki/doch\%C3\%B3d.html (access date: 27.09 .2017$)$.

Matkowski, Z., Próchniak, M., Rapacki, R. (2013a): Nowe i stare kraje Unii Europejskiej: konwergencja czy dywergencja?. Retrieved from: http://cejsh.icm.edu.pl/cejsh/element/bwmeta.1.elem (access date: 27.03.2018, pp. 63-98).

Matkowski, Z., Próchniak, M., Rapacki, R. (2013b). Scenariusze realnej konwergencji w Unii Europejskiej-kraje EŚW a UE-15. IX Kongres Ekonomistów Polskich, Warszawa. Retrieved from: http://www.pte.pl.kongres/referaty/Matkowski (access date: 27.03.2018).

Pojęcia stosowane $w$ statystyce publicznej. Retrieved from: https://stat.gov.pl/(...)/slownik-pojec/(...) (access date: 27.03.2018).

RER. Retrieved from: http://www.ierigz.waw.pl/prace-badawcze/rer (access date: 23.03.2018, pp. 1-12). 


\title{
ZMIANY ZRÓŻNICOWANIA DOCHODÓW ROLNICZYCH W PAŃSTWACH CZŁONKOWSKICH UNII EUROPEJSKIEJ
}

\begin{abstract}
Abstrakt
Po rozszerzeniu Unii Europejskiej (UE) w 2004 roku oraz w latach nastepnych 13 nowo przyjętych państw, w tym Polska (UE-13), zostało objętych wspólna polityka rolna (WPR). Wprowadzone reformy przyczynity się do poprawy struktury agrarnej oraz spadku nakładów pracy w rolnictwie. W rezultacie państwa z grupy UE-13 cechowała wyższa dynamika wzrostu dochodów rolniczych niż państwa o dłuższym stażu członkostwa w UE (UE-15). Celem artykutu jest ocena, czy okres po akcesji cechowat proces konwergencji realnych (w cenach z 2010 roku) dochodów rolniczych $w$ przeliczeniu na jednostkę nakładów pracy, wyrażona w AWU, czy odwrotnie - następowała dywergencja między państwami członkowskimi UE, zwłaszcza między grupami państw UE-13 i UE-15. W tym celu zastosowano metodę analizy porównawczej z wykorzystaniem stosowanych $w$ statystyce miar zróżnicowania rozkładu. Podstawowa baza danych wykorzystywana w badaniu sa Rachunki Ekonomiczne dla Rolnictwa (RER, Eurostat). Badanie obejmuje lata 2004-2016.
\end{abstract}

Słowa kluczowe: dochód rolniczy, akcesja, zróżnicowanie, państwa członkowskie Unii Europejskiej.

Accepted for print: 15.06 .2018 .

Unless stated otherwise all the materials on the website are available under the Creative Commons Attribution 4.0 International license.

Some rights reserved to the Institute of Agricultural and Food Economics - National Research Institute.

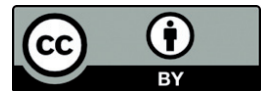

